\title{
The Woman as "the Other" in Glaspell's Trifles, Hansberry's A Raisin in the Sun and Kane's Blasted
}

\author{
https://doi.org/10.33806/ijaes2000.20.2.9 \\ Raad Kareem Abd-Aun and Haneen Ali Haleem \\ University of Babylon, Iraq
}

\begin{abstract}
According to de Beauvoir, gender roles in society are in binary opposition: men are "the One", the absolute and essential, while the women are "the Other", the accidental and inferior. This concept of Otherness is clearly present in various elements of modern plays written by female playwrights in the twentieth century. This notion has been traced back in Susan Glaspell's Trifles through the play's setting and atmosphere, as well as the characters' understanding of "justice". For A Raisin in the Sun by the African American playwright Lorraine Hansberry, women experience the inferiority of being both women and black. Sarah Kane's Blasted, being an example of In-Yer-Face theatre, depicts the emotional and physical abuse of women in (post-) war societies through its harsh and brutal visualization of different forms of violence. By comparing these three different plays, it appears that there is a tendency emerging towards universalism, the "Other" is the experience of all women, at all times which is evident as the selected plays belong to different cultures across the twentieth century.
\end{abstract}

Keywords: A Raisin in the Sun, blasted, gender, "the Other"' Trifles

\section{Introduction}

Socialization shapes ideas about what it means to be a woman or a man. These social identities are created through our ongoing social interaction with other people and our subsequent self-reflection about who we think we are according to these social exchanges. These identities can be divisive and even destructive. (Yousef, 2019: 71) One of the ways in which societies create this sense of belonging and identity is by constructing social categories as binary opposites. According to Hegel, reality is made up of the interplay of opposing forces (1996: 23). Thus for a being to define itself, it must also define something in opposition of itself. In Simone de Beauvoir's words: "The subject posits itself only in opposition" (1989: 27).

This leads to the concept of "the Other". Generally, "the Other" is considered to be an individual who is perceived by a group as an outsider: she or he is culturally constructed as being fundamentally different in some way. The group sees itself as the "standard" and judges those who do not meet certain norms as lacking essential characteristics possessed by them. The "Other" is almost always seen as a lesser or an inferior being and is treated accordingly.

As de Beauvoir points out in The Second Sex, men are "the One", (in other words, being in and of themselves), while the women are "the Other". A woman is "defined and differentiated with reference to man and not he with reference to her; 
she is the incidental, the inessential as opposed to the essential. He is the Subject, he is the Absolute - she is the Other." (de Beauvoir 1989: 16). The difference lies here in the fact that the case of reciprocity is not recognized in this binary opposition, for one of the contrasting terms, the man, is set up as the sole essential, denying any relativity in regard to its correlate, and defining the woman as pure otherness.

Gayatri Spivak defines "the Other" as "the underprivileged and dispossessed Third-World woman who is found beyond the margins of representation." (Kapila, 2009: 422) As apt as this definition might sound, it neglects women who are not in the third world as if their lot is any better. On the other hand, Luce Irigaray claims that the "'feminine' is always described in terms of deficiency or atrophy, as the other side of the sex that alone holds a monopoly on value: the male sex". (Irigary, 1989: 69) This statement accounts for what Spivak neglects in her definition and addresses the dilemma of women not only on terms of sex, but also of race and color.

By comparing the depiction of women in plays by women playwrights from the first world, it seems that there is a sense of universality: "the Other" is the experience of all women, at all times. This sense of universality of the concept of Otherness is clearly present in various plays written by women playwrights which will be critically analyzed to elucidate how women are seen as "the Other" in relation to men in male-dominated societies. The plays chosen for discussion are Susan Glaspell's Trifles, Lorraine Hansberry's A Raisin in the Sun, and Sarah Kane's Blasted. The plays (one from the early, the second middle, and third towards the end of the twentieth century) show clearly that women are treated in a similar way, as the "Other", regardless of the time or culture she belongs to as is shown in the following sections.

\subsection{The insignificant "Other": Susan Glaspell's Trifles}

Susan Glaspell (1882-1948) was an American dramatist, theatre owner, producer, and novelist. Trifles was Glaspell's first play for the Provincetown Players, produced August 1916. Its main source was an actual murder case she covered as a reporter, namely the murder of a sixty-year-old farmer named John Hossack. Having been deeply influenced by it, many of the play's events and details are similar to this murder case. Examples are the wife sleeping beside her husband while he was being killed, neighbors who hinted at a history of marital and family troubles, and that the wife showed no emotions when being arrested. The difference lies in the fate of the two women; Margaret Hossack was found guilty, meanwhile there is no clue as to Minnie Wright's fate. The main evidence against Mrs. Hossack was her emotionless behavior and her not crying on the trial, as might have been demanded of a "proper wife". "The jury may not have been convinced that she was guilty of murder, but she certainly was guilty of questionable female behavior", and it would have been unthinkable to have found such a woman innocent (Ben-Zvi 1992: 152). Women at those times were not accorded the opportunity to speak in the court, so they would not have been able to present their defense. Therefore, Glaspell turns the table: she rewrites the story 
from the point of view of the (previously concealed) wife's motive, giving women the opportunity to reshape the events (Benko 2008: 8) *.

According to de Beauvoir, women are not seen as autonomous beings in a man's world, for men define them only in relation to themselves. Being the Subject grants men the power to shape the world as they see fit and they have created a world where "A man is in the right in being a man; it is the woman who is in the wrong" (de Beauvoir 1989: 18) because she is unable to see the world objectively. This concept of otherness is traced back in many of the play's aspects, one of which is its setting.

Hypothetically, there is a gender-based and hierarchically structured world: there is a sphere for women, an inner, small, airy "bubble" of domesticity, where women are "engaged in nurturing activities, focused on children, and family dependents" (Kerber 1997: 161), and there is another sphere of men, containing the rest (including the power to control the women's sphere). Women's "proper sphere" was regarded to be the private sphere, their home, separated (sometimes even physically) from the public sphere, and this "separation was generally associated with subordination, deteriorating status and the victimization of women by men" (Kerber 1997: 166). This subordination resulted in the emergence of the stereotypical image of women, who were, most importantly, obedient, since "the cardinal virtues associated with women were domesticity, piety, purity and submissiveness" (Kerber 1997: 163). This separation and the concept of "the proper sphere" of women seems well-founded, especially because of the longlasting, subordinating traditions of the (Western and Eastern) cultures: "the separation of spheres was not limited to a single generation or a single civilization" (Kerber 1997: 171), there has always been a distinction between private and public, where "male space tends to fuse with public space, while what is left, is women's space" (Kerber 1997: 188).

In the play, the concept of separate spheres is clearly visible, not only in a theoretical, but also in a material sense. The private (female) and public (male) duality is materialized through the house itself - the kitchen being the "heart of the house", the private, stereotypically female sphere, where the female characters settle, while the other rooms represent a rather public sphere, which the male characters immediately conquer by going around the house, "snooping around" (1113) in search for clues. Both groups, the female and the male, keep the "rules" of these separate spheres as they stay within their own territory: the ladies, being "well-behaved submissive creatures" sit in the kitchen and chat about "insignificant" things, or trifles, while the men go round surveying the whole house and its surroundings (Benko 2008: 11).

In addition, by setting the play in the kitchen, in the private space where Minnie lived, rather than the court, the public space where she will be judged, Glaspell offers the audience a composite picture of the life of Minnie Wright/Margaret Hossack and the countless women whose experiences were not represented in court because their lives were not deemed relevant to the adjudication of their cases. Most importantly, by shifting venue, Glaspell brings into focus the central questions never asked in the original Hossack case: the 
motives for murder, what actually takes place at home, and why women kill (BenZvi 1992: 154).

Glaspell's play provides an illustrative example of how the ability to interpret situations is gender-inflected when it comes to understanding women or the world at large, how dissimilar perspectives women and men have, and how differently they perceive the same things (Kolodny 1980b: 587). The main stress is on the "crucial importance of the sex of the interpreter" as the "female meaning" proves to be inaccessible to "male interpretation" (Kolodny 1980a: 460). In spite of the fact that men control the public authority to interpret the world, yet they are "incapable of adequately 'reading' even the closest women to them, because what is significant to one sex, is not so to the other" (Kolodny 1980b: 588). In interpreting a given situation, men and women have different strategies which "are learned, historically determined, and thereby necessarily gender-inflected" (Kolodny 1980a: 456). Entering the kitchen of Minnie Wright, a supposed murderer, Mrs. Hale and Mrs. Peters are naturally frightened and confused, nevertheless they instantly feel and 'read' the meaning of the disorder in the kitchen both physically and mentally. It conveys different meanings to the female observer, many things draw both parties' attention, but only the women can interpret the implication of these details. These are meaningful parts of a "metaphysical, coded message" (Kolodny 1980a: 462). This presumes that Minnie is communicating through these clues unintentionally. Only through this medium she can "tell" her story to other women - and exclusively to women -for "if the absent Minnie Wright is the 'transmitter', or 'sender' in this schema, then only the women are competent 'receivers' or 'readers' of her message, since they alone share not only her context (the supposed insignificance of kitchen things) but, as a result, the conceptual patterns, which make up her world" (Kolodny 1980a: 462). Accordingly, Mrs. Hale and Mrs. Peters step by step start to pick up bits of information Minnie Wright left, however unintentionally, since "coding needs not to be a conscious act ... and Minnie Wright did not deliberately encode her murderous rage and despair into the chaos of her kitchen and sewing basket, but she nonetheless left a message that the male investigators could not read correctly and their wives could not mis-read" (Radner and Lanser 1987: 1987, 415; Benko 2008: 14).

Men and women have different norms and standards to judge by. In consequence, a man who is regarded as 'a good man' by the patriarchal society he lives in, is not necessarily a good man in a woman's eyes - just as in the case of John Hossack, who, according to the reports of Glaspell and the research done by Linda Ben-Zvi, was a highly respected member of the society, even though he frequently beats his wife and children. The same is true for the "good" (hard working and non-drinker) John Wright who was a cold and controlling man, absolutely different from the joyful Minnie Wright (Ben-Zvi 1992: 142).

This difference in interpreting clues leads to the play's second aspect in which otherness is implied, namely the notion of justice. Though its plot focuses on a single moral choice, that of Mrs. Hale and Mrs. Peters deciding whether or not to expose why Mrs. Wright killed her husband, Trifles is thematically 
complex. It addresses the issue of justice as well as contemporary issues of gender and identity. Susan Glaspell's authenticity comes from the way she interweaves these issues together. When they enter the farmhouse, Mrs. Hale and Mrs. Peters are there as wives, adjunct to their husbands' roles in society. However, through the process of attempting to help another woman by gathering items from her household that might comfort her in jail, they learn to identify themselves first as women and only second as wives. They realize that they are like Minnie Wright, only born to be slightly luckier. Being in the same female sphere, they share a common fate, and this sense of community gives them courage to oppose traditional, conceptual law, and follow their own, "female law". Each woman recognizes her own life in Mrs. Wright's suffering, and comes to see that facing the same circumstances, they, too, would have killed the man that so damaged their lives. From the point of view of the abused housewife, the murder can thus be justified. These women symbolize all women, and this growing awareness suggests the possibility of personal transformation (Benko 2008: 23).

When they decide to hide the evidence related to Mrs. Wright's motive for the murder, the two women are condoning the crime, or declaring that it is not a crime, out of justice against the suffering that John Wright inflicted upon his wife. This stance creates a tremendous moral dilemma. The ideal of justice is that a truly just society is impartial. Yet, all the male characters are blind to the truth that is right in front of them, and are even condescending to the women. This suggests that the entire concept of justice is flawed. Either there are different justices for different groups, according to their experience of the world, or, worse, there are different realities, invisible to those who do not share them (Benko 2008: 59).

Because of their different perspectives, men and women deal with ideas differently as well, just as their concept of morality and justice. In the case of Minnie Wright, law is one thing, and justice is another - Minnie Wright murdered her husband, which was a crime, but John Wright systematically and slowly "murdered" Minnie Wright, and "That was a crime! Who's going to punish that?" (Glaspell 2002: 1118). Law has never been equal to justice nor morals, but it is a traditionally accepted concept that influences power relations and social structures. In addition, as the "public and private" duality can be identified with "men and women", thus "law and morality/(justice)" can be identified the same way with the different sexes. Law represents the powerful public authority, governed by men, its decisions based upon facts, while morality is the immaterial, private "forum" for women, inside the female sphere, where decisions are made according to emotional arguments. The male dominance over the law, the courtrooms and trials are such a powerful stereotype, that there is no wonder "the other side" of the scale, morality, becomes identified with females (Benko 2008: 159).

Mrs. Hale and Mrs. Peters, thus, in the name of moral justice, choose to abide to conceptual law, and hide the incriminating evidence. By saving a particular woman, they - though just in theory - administered justice to every abused housewife, and even strengthen their own "community feeling". The following question arises: with this act, did they "cross the borders" of the female 
sphere or not? In one sense they did: they opposed the stereotypical social order, subverted the law, and they were disloyal to their husbands, but in another sense they did not: they stayed in their own territory, whatever happened took place in the kitchen, their own domain, with "kitchen things" and quilting, through their own "trifles", judging according to their own justice. However morally questionable their concealing pieces of evidences is, it is still compatible with archetypal femininity - to turn past male ideologists' own weapon against themselves. Consequently, interior spaces belong to women, and hiding, covering something, even a dead canary, evokes the concept of including, containing something in an internal space, then the whole matter remains inside the "female sphere" (Benko 2008: 65).

Moving to the reason why Mrs. Hale and Mrs. Peters actually conceal the pieces of evidence, they probably have a complex reason: first of all because of compassion, but probably also because they fear that Mrs. Wright might not get a fair trial in front of a jury composed only of men. They might also wish to strike back against the men, to control a situation in a world dominated by men, to though secretly - display some power over them (Stephens 1989: 53). The pattern is visible, the "quilting of the story" is finished, still it cannot be exhibited, and the women have to remain silent to reach their aim. It is interesting to point out that since Mrs. Hale and Mrs. Peters had solved the mystery, they could have shown it off to their husbands, and changed the men's attitude towards them accordingly, but for the sake of Minnie Wright they endure still being looked down upon. This implied sacrifice strengthens the sense of community these two women feel: "By finding and concealing the incriminating evidence, the women win their own individual victory, but the system remains intact" (Stephens 1989: 53).

It may seem strange that when Glaspell has the opportunity to change the outcomes of Margaret Hossack's case, she does not acquit the woman. Instead, she has Mrs. Peters and Mrs. Hale assume Minnie's guilt and - as in the original trial - base their findings on circumstantial evidence instead of incontrovertible proof. However, when approaching Trifles in relation to the Hossack case, it becomes clear that acquittal is not Glaspell's intention. Whether Margaret Hossack or Minnie Wright committed murder is moot; what is incontrovertible is the brutality of their lives, the lack of options they had to redress grievances or to escape abusive husbands and the complete disregard of their plight by courts of law and by society. Instead of arguing their innocence, Glaspell concretizes the conditions under which these women live and the circumstances that might cause them to kill. She thus presents the subtext that was excised from the original trial (Ben-Zvi 1992: 62).

\subsection{The racial "Other": Lorraine Hansberry's A Raisin in the Sun}

Lorraine Hansberry (1930-1969) was an African-American playwright and activist. She grew up in a middle-class family, born to parents who were welleducated, black citizens who fought discrimination against black people. Hansberry attended the University of Wisconsin-Madison for two years, and took several courses at Roosevelt College in Chicago and the University of 
Guadalajara in Mexico. In 1950, she dropped out of college and moved to New York City where she took writing classes at the New School for Social Research, and worked as an associate editor of Freedom newspaper. During this period, she met many notable African-Americans who influenced her, including Langston Hughes, from whose famous poem "Harlem: A Dream Deferred" Hansberry took the title of her play A Raisin in the Sun (Bloom 2009: 9).

Hansberry finished writing A Raisin in the Sun in 1957, and it was first performed in New Haven, Philadelphia. This play contains autobiographical elements. As a child, Hansberry's family moved from the Chicago projects to an all-white neighborhood and she attended a predominately white public school. They faced intense racism, and their home was even attacked by a mob. Her father eventually engaged in a legal battle against the attempt to prohibit African American families from buying homes in particular neighborhoods. Years later at college, she saw a performance of Sean O'Casey's Juno and the Peacock about the struggles of a poor Irish family, and she knew that she wanted to tell a similar realistic story about the oppression of African-Americans. She felt the inclination to record her experiences, and through this play she became one of the first playwrights to create a realistic portrait of African-American life (Bloom 2009: $10,13)$.

Hansberry provides an authentic representation of women's position in society and their relationships to men. Through the characterization of the three African-American women at the core of her story, Hansberry's A Raisin in the Sun uncovers some of the social and cultural issues prevalent in mid-20th century American life, especially those of race, class and gender. It provides an investigation of the identity of African-American women in relationship to their male counterparts in terms of appearance and other gender-related expectations, naming/renaming themselves, and the division of burdens and responsibilities (Jeffries 2013: 24, 25). As the metaphorical title of the play suggests, Hansberry's purpose is to "deconstruct the Black experience around the possibility of sweet triumphs amidst the sour obstacles African Americans meet in American society" (Jeffries 2013: 22).

Beneatha is the youngest and most spirited female character in Hansberry's play. As a 20-year-old Black female college student living in a cramped subsidized apartment space with her mother, brother, nephew, and sister-in-law, she embodies an intellectual Black woman of that time. She aims at taking control of her economic situation and her identity by actively pursuing her education, working toward her goal to be a doctor, and expressing her contentment with not marrying if she so chooses. Through her interaction with the men in the play, Beneatha challenges the traditional, stereotypical norms of the male dominance that are expected from women (Jeffries 2013: 25, 37).

Conflicting views arise as the family discusses how their recently inherited insurance money is to be spent, and a sibling rivalry occurs between Beneatha and her brother Walter. Walter hopes to start his own business, a liquor store, attempting to help alleviate the family's financial difficulties, while Beneatha wants to pay for medical school tuition and be able to give back to the family in 
the future by securing a job in the health profession (Jeffries 2013: 26). Walter, unable to cope with the idea of a woman in control, suggests the proper place for women, and displays his need to be right or in control: "Who the hell told you to be a doctor? If you so crazy 'bout messing 'round with sick people - then go be a nurse like other women - or just get married and be quiet ..." (Hansberry 1994: 26). This conveys Walter's belief of women's appropriate roles as "the other". Walter cannot fathom his sister becoming a doctor rather than a nurse, as the former profession is male dominated. Moreover, he believes that a woman's role is to simply complement the man; thus, Beneatha should either be the doctor's nurse if she must work, or be the man's wife, if she takes her proper role at home. Further, he argues that she should be quiet, because it is ridiculous for her to think that she can verbally challenge a man, who is the head of the family, the workplace, and society in general. Beneatha, however, pays her brother no attention, and like most women, Black women in particular; she is concerned with how her financial decision will affect the rest of her family, rather than just herself and her immediate desires or needs. With her goal of being a doctor, she aims at challenging dominant White society (and Black men) and overcome economic disenfranchisement (Jeffries 2013: 26).

During the course of the play, Beneatha goes back and forth between two very distinct suitors, including the native and proud African, Joseph Asagai, and the quite conservative, haughty George Murchison. Her gentlemen callers represent the two opposite extremes of the stereotypical Black male during the riotous political scene of the late 1950's (Jeffries 2013: 27). Influenced by her native African boyfriend, Asagai, Beneatha shows much pride in her race, and is delighted when he gives her authentic Nigerian robes. He calls her an assimilationist and criticizes her "mutilated" hair, preferring the natural look she was "born with" (Hansberry 1994: 48). Next, he gives her a tribal name based on her lack of conformity to his desires: "Alaiyo... meaning One for Whom BreadFood-Is Not Enough" (Hansberry 1994: 52). The name Asagai assigns Beneatha is affirming in the female empowerment sense, however, and reflects her choice to define herself apart from her relationship with him, and therefore, asserts her own voice over his (Jeffries 2013: 27). A liberated woman indeed, Beneatha also challenges the opinions of her other suitor, George Murchison, who expresses his distaste with her "eccentric" look. Beneatha is disgusted with her disenfranchised status, and the dominance of White societal norms which even determines the appropriate style of dress and decorum for events. George encourages Beneatha to suppress her "eccentric" and quite possibly authentic African-American culture, because he fears discrimination by White society (Jeffries 2013: 28).

Moving to the other female characters in the play, it is noticed that they occupy a slightly different role, a matriarchal one. In tracing the historical roots of the matriarchal stereotype, the following can be inferred: "The Black matriarchy regards the Black male as 1. undependable and is frequently responsible for his emasculation, 2. is often very religious, 3. regards mothering as one of the most important things in her life, and 4. attempts to shield her children from and to prepare them to accept the prejudices of the White world." (Anderson 2009: 60, 
61). A Raisin in the Sun is a play about matriarchy. Mama, Mrs. Lena Younger, is a matriarch, and Ruth, her daughter-in-law, struggles with the matriarchal role (Anderson 2009: 61).

Initially, the play celebrates Mama's role as the African-American mother and head of the household, who is ultimately in charge and expected to make the most rational decisions for the family. Mama (Lena) Younger is made to function as both parents at the play's beginning when Big Walter Lee, the father, dies (Jeffries 2013: 34, 35). The money Mama is about to receive from her late husband's insurance will bring hope and dreams into the bleak existence of the Youngers, as every member has plans on how to spend it.

What is a bit disappointing is that Mama relinquishes her control by giving Walter control over the greater part of the money. This important moment of trust, in which Mama hands over to Walter the family's financial livelihood, as well as the title of head of the household, later becomes devastating when it is discovered that Walter has disobeyed her advice by investing all of the remaining money in the liquor store, and that his so-called partner, Willie, has run off with it, never to be seen again. Though Walter respects his mother and wants to please her, his desire to be the breadwinner and fulfill the stereotypical male head of the household role ultimately overshadows his initial obedience. This leaves the family in the same position of economic burden they were in at the beginning of the play, but with a feeling of loss and inability to attain financial progress, proving Walter to be undependable and indeed responsible for his own emasculation (Jeffries 2013: 36).

Mama embodies the second trait of the matriarchal stereotype. Religion is an integral part of her life, and she wants her children to incorporate her religious ideals into their lives. This wish is most evident when she slaps Beneatha for saying there is no God and makes her repeat, "In my mother's house there is still God" (Hansberry 1994: 39). When Mama is furious at Walter for losing the insurance money and is at a moment of great need, she asks God for strength. Her faith sustains her and gives her the strength to be a matriarch (Anderson 2009: 62).

Mama also possesses absolute devotion to her family. Her dreams and reasons for existence are her family. She quotes her late husband to Ruth: "'Seems like God didn't see fit to give the black man nothing but dreams - but He did give us children to make the dreams worthwhile'" (Hansberry 1994: 33). The most important things in her life are her children, and Mama is willing to sacrifice anything for her family. When Ruth suggests that she should use the insurance money to take a trip, Mama explains that she could never spend the money on herself, but must spend it on the family. Mama decides that the best way to safeguard her family is to move them to a house where they can escape the tensions that plague them (Anderson 2009: 62). This remark by Mama actually reinforces her role in society, not only as a mother, but as an African-American mother, with less financial freedom than most White mothers during that era. It sheds light not only on the economic disenfranchisement of African-Americans of this era, but on the fact that many African-American mothers had to provide for 
their families on their own, and therefore, did not have the privilege of spending money the way that meets their own desires (Jeffries 2013: 35).

Within as well as beyond her family, however, Mama Lena is a loner, which appears to be a serious consequence of the strong black woman character. As head of her household, Mama Lena obviously has no peer. The hierarchy of power established within the family illustrates clearly that she has no one at all to whom she can turn - even if she wanted to - for consultation about the decisions she makes. Her position and power leave her without a shoulder to cry on, without a designated sympathetic soul mate. Mama embodies the classic example of the problematic nature of the black female character's strength (Harris 2009: 119, 120).

Shifting to the last female character, Ruth is a woman of thirty, married to Walter Lee Jr., the "man" of the house. Although Ruth is not the matriarch of the family, in her relationship with Walter, one can see the first trait of matriarchy. She often sides with Mama and shares her basic distrust of Walter's plans and doubts his judgment. Like Mama, she is emasculating Walter and keeping him from asserting himself as protector of the family. At the beginning of the play, when Walter wants to discuss his dreams with her, she answers him with, "'e'at your eggs, they gonna be cold" (Hansberry 1994: 21). She mothers him instead of listening to and responding to his needs (Anderson 2009: 62).

While Ruth often rolls her eyes at Walter's sexist comments and bizarre behavior, she is much less liberated and direct than Beneatha, in the sense that she usually glares at him in disgust, rather than voicing her alternate opinion. And while there are times that she does not agree with Walter on a particular issue, she oftentimes reinforces conventional standards or beliefs professed by him or men in general. Though maintaining peace seems to be her primary concern, she acknowledges her position and challenges oppressive male dominance or wrongdoing in some instances. Additionally, she shows independence in making some of her own decisions (Jeffries 2013: 37).

Though Ruth's approach is quite passive in comparison to Beneatha's, she does not always let Walter run over her. When he questions her mood, she answers: "What is there to be pleasant about?" (Hansberry 1994: 20). Unconcerned with her feelings, Walter continues to assert his masculinity, complain about their economic status and suggest that Ruth should be his support system, to which she is not exactly in agreement (Jeffries 2013: 31). Instead of being sympathetic and reasonable, he begins a tirade about how the woman's role is to complement the man, being nothing more than "the other": "A man needs for a woman to back him up [...] That is just what is wrong with the colored woman in this world [...] Don't understand about building their men up and making 'em feel like somebody. Like they can do something." (Hansberry 1994: 22). Instead of uplifting Ruth and recognizing how valuable she is as his wife and as a mother, he insults and dismisses her as unimportant and unintelligent. Unfortunately, although Walter belongs to the same racial group as his wife, he highlights the problematic dynamic of male domination that places the Black woman at the bottom of the socioeconomic scale as a whole. Ruth, exhausted by his 
commentary, ignores his ignorance and internalizes her response, though she later takes full advantage of opportunities to expose his foolishness. For instance, she teases him when he later leaves for work, needing money for carfare. Ruth slyly gives Walter an additional fifty cents since he has given his own money to their son, and teases him with the same words he used in an attempt to spoil Travis: "Here, take a taxi" (Hansberry 1994: 27). Knowing he will lose this battle, Walter says nothing and leaves for work. Even though Ruth's responses are not as outright as Beneatha's, she gets Walter to back down in her own way, which eventually proves effective.

Eventually, they proceed with moving into the house, hoping that they will find a way to move forward with their lives and not let economic stress define their existence. In spite of the frustrating moments and their given circumstances, these strong Black female characters find various opportunities to define themselves and prevail. Understanding that the otherness they are coping with is a result of race, class, and gender constructions, they work hard against them to provide for their family and themselves.

\subsection{The "Other" as object of rape: Sarah Kane's Blasted}

Sarah Kane (1971-1999) was an English playwright. Despite Kane's long history of severe depression, she wrote five plays throughout her short life and was eventually being "hailed as the young playwright of her generation", enjoying success at a very young age. Kane died in 1999, when, two days after taking an overdose of prescription drugs, she committed suicide by hanging herself in a bathroom at London's King's College Hospital. (Quinn 1999)

Rape is "engendered" in the sense that regardless of whether the victim of rape is male, female or an inanimate object, it is always perceived socially and culturally as feminine. Rape is violence done exclusively to a feminine "other", which makes rape a deeply engendered form of sexual violence. While it may not be exclusively practiced on women, "rape is sexual essentially because it rests on the very social difference between the sexes. If men rape women, it is precisely because they are women in a social sense" and when a male is raped, he, too, is raped "as a woman" (Lauretis 1989: 244). In other words, any "One" gives himself the right to rape any person occupying the position of "the Other", whether male or female, who is assumed to be a woman "in a social sense".

Kane seems to pick up on this contention when she carefully constructs binary gender oppositions between a naïve and impressionable Cate and a masochistic Ian on the one hand, and later on reverses this by ascribing to Ian the role of the passive and weak (feminine) victim, "the Other", of aggressive masculine violence, the Soldier as the "One", on the other (Zhurba 2008: 6).

Ideally, playwrights want audiences to feel involved in or a part of their plays. During the 1990's, the British "In-Yer-Face" theatre emerged. It is characterized by the "shock vest of violence, taboo-breaking drama by a new wave of angry young men and a few young women - most significantly Sarah Kane" (Aston 2010: 580). Aleks Sierz defines In-Yer-Face theatre as a kind of drama which "takes the audience by the scruff of the neck and shakes it until it 
gets the message" (2001: 4). It mirrors the insensitive and reckless side of society and brings the audience on the verge of facing themselves in the sense of reality. One of the characteristics of this new genre of drama was its intense embrace of sex and violence. Violence certainly emerged as a defining feature of Kane's writing, and when she sought to intensify the violence of her plays, Kane repeatedly returned to rape (Ward 2013: 225).

Being full of shocking elements like suicide, nudity, cannibalism, and visualized sexual violence, Kane's first play, Blasted, is a prominent work within In-Yer-Face theatre. This play proved that Kane can "flex her muscles alongside the toughest of men ... beating male playwrights at their own game" (Luckhurst 2005: 108). To a certain extent, it represents how incidents like rape highlight and solidify the unevenness of power distribution between men and women in the modern world and provides a new perspective at what we might call "rape" in general, as a "transhistorical phenomenon [which is] a practice of violence against the female victim" (Zhurba 2008: 2).

Rape is "a crime that epitomizes women's oppressed status", in other words it is the ultimate metaphor for domination, violence, subjugation and possession (Cahill 2001: 2). In the general orientation of the "real rape stereotype", here are four particular rape myths commonly identified. The first suggests that only women are raped. The second supposes that only a certain type of women is raped, those who "had it coming". The third implies that alleged rapists are often "led on" to such a degree that they cannot be held responsible for their actions. Eventually the fourth one, the most enduring myth of all, is that "real" rape is "stranger" rape (Bohner 2009: 18, 19). These four myths are challenged through Kane's characterization of Cate and Ian.

To begin with, the first rape scene follows classic gender roles. "The significantly stronger male character overpowers the weaker female" (Zhurba 2008: 23). Cate's rape takes place between the first and second acts of the play. It is not as such a domestic environment, but it is an environment in which a form of rape familiar in domestic environments can take place. She is also raped by someone she knows: Ian who is not a "stranger". All the myths of the victim who should have seen it coming, who failed to take evasive action, who somehow contributed to her own violation, are present. The tragedy particularly lies in the predictability. Cate knows Ian, she knows his tendency towards violence, and yet she still accepted an invitation to come up to his room simply because he sounded unhappy (Ward 2013: 230, 231).

Cate gets consistently raped throughout the play. She is raped twice: at the beginning of the play (accompanied by the metaphor of scattered flowers that serves as a frame for the narrative, reappearing at the end of Blasted) and later outside of the hotel. Symbolically, she is also raped via language by various practices of social disempowerment (for instance, her fainting spells and Ian's verbal abuse). Whether she stays in the hotel or makes it to the outside world, what awaits her is nothing but rape, as if it is the common condition for a woman in the contemporary world (Zhurba 2008: 10). 
The first rape is staged within the tradition of representing the most violent acts off-stage. The audience is protected from witnessing Ian's violation of Cate, however, the playwright provides enough evidence to assume that Cate gets raped between the first and second act. Taking into account the brutality of Ian's visibly represented rape later in the play, it is particularly surprising to note that Kane poetically covers up Cate's rape metaphorically through the bouquet of flowers that is been ripped apart and scattered around the room at the opening of the second act. Kim Solga claims that the choice not to stage Cate's is intentional, launching the author's critique of the systematic social and generic disavowal of rape in representation (2007: 349).

In fact, the metaphor of scattered flowers becomes a motif that runs through the whole play. When Cate is seen the first time on stage, she smells the flowers and smiles. After she rejects Ian's invitation to make love, the stage directions that close the first scene do not imply any violence, but rather end the scene on an almost romantic gesture from Ian: "(Turns away. He sees the bouquet of flowers and picks it up.) Ian: These are for you" (24). From the opening of the following scene we find out that the characters had some kind of fight as "The bouquet of flowers is now ripped apart and scattered around the room" (24). The immediate dialogue between Cate and Ian confirms the audience's suspicion that Cate was raped by Ian. The symbol of the torn bouquet returns in the final scene when Cate comes back to the hotel to find a violated and disabled Ian: (Zhurba 2008: 22) "She collects a few of the scattered flowers and places them under the

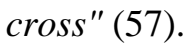

Later, when the Soldier realizes that Cate has escaped the Leeds hotel through the bathroom window, he does not get upset over not being able to carry an act of revenge upon Ian as an enemy male through raping his woman. He immediately predicts that, no matter what, she will be raped out there: "Gone. Taking a risk. Lot of bastard soldiers out there" (38). He knows that somebody will take care of violating Ian's girlfriend for him, for Cate's lot is to be raped. Moreover, raping women is what the Soldier expects soldiers to do at war (28). The stage directions tell us that Cate (in accordance with the Soldier's prediction) gets raped off-stage a second time after escaping from the hotel. She returns with "blood seeping from between her legs" (60) (Zhurba 2008: 28, 29).

In examining the characters in Blasted, it is hard to make a clear distinction between victims and perpetrators. The most obvious victim, however, is Cate. She suffers from epilepsy, is unemployed, sucks her thumb throughout the play and is abused by Ian, a much-older man. Despite continuous ill-treatment from Ian, she always worries about him and keeps coming back, fully complying with the label of a "masochistic woman" (Zhurba 2008: 19). Yet, in light of the feminist attempts to eliminate gender roles, the play could be interpreted as a "progressive aesthetic representation of how finally the fundamental binary opposition of the feminine and masculine could be destroyed", providing the narrative about the raped man (Zhurba 2008: 4). 
Considering the myths of the stereotypical rape, critics have tended to focus on Ian's rape as the "real" rape in Blasted, for three reasons: the physical event is actually presented onstage, rather than merely simulated; it is overtly violent; and the Soldier is a stranger. It is also, of course, an instance of male rape, something which violated the initial myth of female victims (Ward 2013: 234). Since the Soldier is looking for a "she" object as soon as he enters, it becomes evident that from the very start he intends to abuse a woman. In this scene, war and the practice of revenge upon the enemy male through the sexual violence towards his woman create a space that subordinates and feminizes Ian, making him the physical victim of a highly traumatized and disturbed Soldier. As there is no object that is of female sex, he rapes Ian still thinking of it as a revenge upon men. The Soldier introduces the war aspect to rape and the total domination of the male with a gun over a symbolic female defenseless object (Zhurba 2008: 26, 27). As long as the Soldier is armed, he is in control, the "One", leaving the unarmed Ian to the position of "the Other", a substitute for the unarmed, defenseless, female "Other". Rape is considered an unfortunate and inevitable by-product of war. Apparently, abusing women in front of their men is the most satisfying act, turning women's bodies into the battlefield of revenge. In war, more frequently women have to pay for real or alleged, previous or actual acts of their male relatives or just fellow countrymen. By drawing parallels between domestic violence and war, and between emotional and physical abuse, Kane managed to portray Cate's experience as the universal experience of all abused women.

In relation to Blasted, it seems illegitimate to speak of violence in such a poetic form at the end of the play after such graphic representation of the Soldier's brutality committed upon Ian. Indeed, it is an emotional challenge for the audience to see Cate collecting flowers from the floor and be able to resist a feeling of desperate powerlessness caused by the vivid representation of violence. However, Kane found a way to express a sense of hope through Ian's "Thank you" to Cate at the end of Blasted, thus leaving hope that no matter how much they were battered and violated, the ideals of youth, femininity and maternity represented in the gesture of gathering flowers would save the world. At the same time, even though Cate appears to be much stronger at the end of the play as opposed to Ian, somehow, there is neither hope for a social change for her, nor for a break through from the rhetoric of violence (Zhurba 2008: 23).

It is interesting to point out that the location where the events take place is unspecified, but it seems to be happening somewhere in Leeds. This sense of ambiguity and the lack of details imply that the experiences depicted on stage could be experienced by any woman in any (post-)war society, thus introducing a sense of universality: the otherness of women in such a position is the same everywhere.

\section{Conclusion}

The otherness of women stems from man's instinctive need for control and validation, control being the epitome of the patriarchal society. Man seeks to dominate his environment, including women, to ensure survival, the continuance 
of the society they have created. Arguably, women have been the greatest challenge to man's control. Men always seek to objectify women, thinking they could lift themselves up by pulling others down.

The notion of being "the Other" creates a paradox for women, as her transcendence ultimately becomes her struggle in society. When free, woman possesses the power to create for herself the paradise which she seeks, but by doing so she creates the ability of being attacked by men because she no longer fills the constructed role. Men's fear of women's transcendence has led to the systematic creation of myths which seek to deter women and cage them in the grasp of male servitude.

Women who achieve transcendence, reject the passivity imposed on them and attain some mastery over their lives are looked on unkindly by patriarchal society. The plays discussed above embody woman's struggle to save her identity and the extent to which otherness have determined almost all aspects of their life. They also proved man's incapability of coping with women as equals to them, due to their instilled sense of self-doubt and inferiority, and constant fear of not measuring up to certain standards.

In Trifles, due to the their ignorance and lack of understanding, men have proved themselves to be fools, for the women made use of being positioned as "the Other" and beat them at their own game. If only the men regarded their wives as equals and did not neglect the importance of their perspective and of trifles, the case would be solved.

In A Raisin in the Sun, all male characters express their fear of woman transcendence in a different way. Walter, believing to be deprived of the "privilege" of being the head of the family, keeps nagging to have the last word over how to spend his father's money. As soon as they agree to let him be responsible for the inherited money, he proved not to be capable of managing a controlling role, for he loses the money. The same goes for Asagai and George. Asagai tries to pull Beneatha down by convincing her to "embrace her origin" and move back to Africa. It seems like he cannot cope with the success of a young, black woman in a white society. George, on the other hand, wants Beneatha to stay, but does not wish to see her as a successful person in society. He wants her to neglect her origin and accept her life as an oppressed, black woman in a white society. He wishes to silence her so that she cannot speak up against the white oppressors.

Finally, in Blasted, Cate represents hope in a (post-)war society. She is the only one who could adapt to the changes in the environment, and stay optimistic to ensure the continuity of life. All men, whether they participated in the war or not, got depressed after experiencing the cruelty of war. Both Ian and the Soldier could not absorb nor find a reason to live, and therefore committed suicide directly (the Soldier) and indirectly (Ian not taking care of his health). Cate is the only one who possesses the strength and courage to embrace life and live on after the disasters she witnessed.

All women, regardless of time and place, experience the same kind of oppression within society and the women in the plays discussed prove to be able 
to master the situation they have been positioned in, and manage to flourish, shattering the patriarchal society's dominant stereotypes which turns them into "Others".

Raad Kareem Abd-Aun

University of Babylon, Iraq

Email: abdaun.raad@gmail.com

Haneen Ali Haleem

University of Babylon, Iraq 


\section{References}

Anderson, Marie Louise. (2009). "The Play's Portrayal of Women", Bloom's Guides: A Raisin in the Sun, Ed. Harold Bloom. New York: Chelsea House. 60-63.

Aston, Elaine. (2010). "Feeling the Loss of Feminism: Sarah Kane's Blasted and an Experiential Genealogy of Contemporary Women's Playwriting." Theatre Journal. 62.4: 575-591.

Beauvoir, Simone de. (1989). The Second Sex. New York: Vintage Books.

Ben-Zvi, Linda. (1992). "Murder, She Wrote. The Genesis of Susan Glaspell's Trifles." Theatre Journal. American Scenes. 44.2: 140-162.

Benko, Zsuzsanna. (2008). Feminine Trifles: The Construction of Gender Roles in Susan Glaspell's Trifles and in Modern English and American Crime Stories. Unpublished MA Thesis. Pázmány Péter Catholic University.

Bloom, Harrold, ed. (2009). Bloom's Guides: A Raisin in the Sun. New York: Chelsea House.

Bohner, Gerd et al. (2009). "Rape Myth Acceptance: Cognitive, Affective and Behavioural Effects of. Beliefs that Blame the Victim and Exonerate the Perpetrator" Rape: Challenging Contemporary Thinking. Ed. Miranda Horvath and Jennifer Brown. London: Willan. 17-45.

Cahill, Ann. (2001). Rethinking Rape. Ithaca, NY: Cornell University Press.

Glaspell, Susan. (2002). "Trifles." The Heath Anthology of American Literature. Ed. Lutner, Paul Vol. 2. (4th ed.) Boston \& New York: Houghton Mifflin Company. 1169-1179.

Hansberry, Lorraine. (1994). A Raisin in the Sun. New York: Vintage Books.

Harris, Trudier. (2009). "Portrayals of Strong Black Women", Bloom's Guides: A Raisin in the Sun, Ed. Harrold Bloom. New York: Chelsea House. 108-124.

Hegel, Georg W. F, and John O'Neill. (1996). Hegel's Dialectic of Desire and Recognition: Texts and Commentary. Albany: State University of New York Press.

Irigaray, Luce. (1985). This Sex Which Is Not One. Trans. Catherine Porter with Carolyn Burke. Ithaca, New York: Cornell University Press.

Jeffries, Devair. (2013). Black Feminine Identity: An Examination of Historical and Contemporary Dramatic Texts through a Critical Race Theory Framework. MA Thesis. University of South Carolina.

Kane, Sarah. (1996). Blasted. London: Methuen Drama.

Kapila, Shuchi. (2009). "The Other". In Encyclopedia of Feminist Literary Theory. Ed. Elizabeth Kowaleski Wallace. London and NY: Routledge. 421-3.

Kerber, Linda K. (1997). "Separate Spheres, Female Worlds, Woman's Place: The Rhetoric of Women's History." Toward an Intellectual History of Women. Essays by Linda K. Kerber. Chapel Hill \& London: Univ. North Carolina Press: 159-200. 
Kolodny, Anette. (1980a). "A Map for Rereading: or, Gender and the Interpretation of Literary Texts." New Literary History. On Narrative and Narratives II. 11.3 (Spring): 451-467.

Kolodny, Anette. (1980b). "Reply to Commentaries: Women Writers, Literary Historians, and Martian Readers." New Literary History, On Narrative and Narratives. 11.3: 587-592.

Lauretis, Teresa. (1989). "The Violence of Rhetoric: Considerations on Representation and Gender". The Violence of Representation: Literature and the History of Violence. Ed. Nancy Armstrong and Leonard Tennenhouse. London and New York: Routlege, 239-255.

Luckhurst, Mary. (2005). "Infamy and Dying Young: Sarah Kane, 1971-1999" Theatre and Celebrity in Britain, 1660-2000. Eds. Mary Luckhurst and Jane Moody. New York: Palgrave Macmillan. 107-124.

Quinn, Sue. "Suicidal Writer Was Free to Kill Herself" The Guardian, www.theguardian.com/uk/1999/sep/23/2. Accessed 18 April 2018.

Radner, Joan N. and Susan S. Lanser. (1987). "The Feminist Voice: Strategies of Coding in Folklore and Literature." The Journal of American Folklore. Folklore and Feminism. 100.398: 412-425.

Sierz, Aleks. (2001). In-Yer-Face Theatre: British Drama Today. London: Faber and Faber.

Solga, Kim. (2007). "Blasted's Hysteria: Rape, Realism, and the Thresholds of the Visible." Modern Drama 50.3: 346-374.

Stephens, Judith L. (1989). "Gender Ideology and Dramatic Convention in Progressive Era Plays 1890-1920." Theatre Journal. 41.1: 45-55.

Ward, Ian. (2013). "Rape and Rape Mythology in the Plays of Sarah Kane." Comparative Drama. 47.2: 225-248.

Yousef, Tawfiq. (2019). "Cultural Identity in Monica Ali's Brick Lane: A Bhabhian Perspective." International Journal of Arabic-English Studies (IJAES) 19:1, 71-86. https://doi.org/10.33806/ijaes2000.19.1.4.

Zhurba, Dina. (2008). The Engendered Representation of Sexual Violence in Sarah Kane's Blasted. MA Thesis. University of Richmond.

\section{Endnote}

"Excerpted from Zsuzsanna Benko. (2008). Feminine Trifles: The Construction of Gender Roles in Susan Glaspell's Trifles and in Modern English and American Crime Stories. Unpublished MA Thesis. Pázmány Péter Catholic University. 